\title{
Арабское завоевание Антиохии и завершение позднеантичной истории города
}

\author{
Иваницкая Я.Ю. ${ }^{1}$, Немыкина Е.В. ${ }^{1}$, Бузанаков Ю.В. ${ }^{2}$ \\ ${ }^{1)}$ МОУ «Стрелецкая СОШ» Белгородского района Белгородской области, \\ Россия, 308511, Белгородская область, Белгородский район, с. Стрелецкое, \\ ул. Краснооктябрьская, д. 148 \\ 2) Белгородский государственный национальный исследовательский университет, \\ Россия, 308015, г. Белгород, ул. Победы, 85 \\ E-mail: buzanakov.ura@yandex.ru
}

\begin{abstract}
Аннотация. В статье представлена история взаимоотношений арабских племен и Антиохии Великой c IV по VII век. Несмотря на то, что Антиохия Великая находилась на периферии арабовизантийских контактов, грабительские походы номадов иногда достигали столицы провинции Сирия, кроме этого войска сарацин играли далеко не первую роль в арабо-персидских войнах. Стоит отметить, что в Антиохии располагался Комит Востока, в чью сферу ответственности входили дипломатические отношения с номадами. Безусловно, ключевым событием в истории города, связанным с арабскими племенами, становится завоевание города сарацинами в VII веке. Это событие завершает ранневизантийский период в истории города. Необходимо заметить, что арабское «иго» население Антиохии приняло более охотно, чем византийское, и не спешило вернуться в лоно империи.
\end{abstract}

Ключевые слова. Ранняя Византия, Антиохия, арабы, доисламский период, арабские завоевания.

Для цитирования: Иваницкая Я.Ю., Немыкина Е.В., Бузанаков Ю.В. 2021. Арабское завоевание Антиохии и завершение позднеантичной истории города. Via in tempore. История. Политология, 48 (2): 318-327. DOI: 10.52575/2687-0967-2021-48-2-318-327.

\section{Arabic conquest of Antihochy and the end of the late ancient history of the city}

\author{
Yana Yu. Ivanitskaya ${ }^{1}$, Elena V. Nemykina ${ }^{1}$, Yuriy V. Buzanakov ${ }^{2}$ \\ ${ }^{1)}$ Municipal educational institution «Streletskaya Secondary School» of the Belgorod District of the \\ Belgorod Region, Russia, \\ 148 Krasnooktyabrskaya St., Streletskoe village, Belgorod region, 308511, Russia \\ ${ }^{2)}$ Belgorod National Research University, \\ 85 Pobeda St, Belgorod, 308015, Russia \\ E-mail: buzanakov.ura@yandex.ru
}

\begin{abstract}
The article presents the history of the relationship between the Arab tribes and Antioch the Great from the 4th to 7th centuries A. D. Despite the fact that Antioch the Great was on the periphery of Arab-Byzantine contacts, nomad predatory campaigns sometimes reached the provincial capital of Syria, in addition to this, the Saracen troops played far from the first role in the Arab-Persian wars. It is worth noting that the Komit of the East was located in Antioch, whose sphere of responsibility included diplomatic relations with nomads. Of course, the key event in the history of the city associated with Arab tribes is the conquest of the city by the Saracens in the 7th century A. D. This event completes the Early Byzantine period in the history of the city. It should be noted that the Arab «yoke» of the population of Antioch was more readily accepted than the Byzantine one and was in no hurry to return to the bosom of the empire. This is due to a number of circumstances, including the difficult religious situation in the region.
\end{abstract}


Keywords. Early Byzantium, Antioch, Arabs, pre-Islamic period, Arab conquests.

For citation: Ivanitskaya Ya.Yu., Nemykina E.V., Buzanakov Yu.V. 2021. Arabic conquest of Antihochy and the end of the late ancient history of the city. Via in tempore. History and political science, 48 (2): 318-327 (in Russian). DOI: 10.52575/2687-0967-2021-48-2-318-327.

\section{Введение}

Арабские племена сыграли важную роль в истории Антиохии Великой. Принято считать, что именно арабское завоевание города в первой половине VII века завершает ранневизантийский период его истории. Однако данные исследований и источников подтверждают контакты Антиохии и арабских племен и в доисламское время. В нашей статье мы попытались проследить историю взаимоотношений ранневизантийской Антиохии и арабов с IV по VII век, оценить их вклад в развитие города.

\section{Результаты и их обсуждение}

Обозначим общий контекст арабо-византийских отношений с IV по VII век. Согласно мнению ученых, в IV веке Византия начинает выстраивать свою политику по отношению к арабским племенам. Не вызывает сомнений, что эта политика строится на «римском» фундаменте. Ряд исследователей считает, что в эпоху Принципата защита арабского участка римской ближневосточной границы во многом была поручена и доверена арабским племенам, союзным Риму: они обороняли римскую территорию на протяжении вверенного им определенного участка границы [Мехамадиев, 2018, с. 39-40]. При этом посредниками во взаимоотношениях императорских чиновников с племенами кочевников были представители племенной аристократии арабов либо непосредственно вожди отдельных родов или кланов, которые вербовали из среды своих соплеменников войсковые группы и приводили их на службу в римскую армию, взамен получая от империи престижные титулы и денежные платежи. Сами войсковые группы несли свою службу непосредственно в пределах провинции Аравия, они располагались на римской территории в качестве специальных пограничных гарнизонов [Грушевой, 2007, с. 345-347].

Византийская литература IV-V вв. отражает два направления политики империи в отношении арабов. Первое заключается в стремлении их подчинить или привязать договорными обязательствами, осуществлявшимися путем оружия или дипломатических сношений. Другим методом, которым империя пыталась приблизить к себе арабов, как и другие «варварские» народности, было приобщение их к своей культуре, в частности к религиозной идеологии - христианству [Пигулевская, 1964, с. 20].

Наиболее информативным источником по истории позднеантичных сарацин является сочинение Аммиана Марцеллина. В нем сохранился один экскурс о них и содержится описание персидского похода императора Юлиана, где вспомогательные арабские отряды играют довольно важную роль (Amm. Marc. XIV. 4.1-7; XXIII. 3.8; XXIV. 2.8; XXV. 6.9). Помимо произведения Аммиана, сведения о сарацинах - федератах Римской империи содержат эпиграфические источники. В основном, это надписи арабских вождей из различных районов Палестины и Аравии [Ермолова, 2007, с. 6].

Аммиан Марцеллин, сам будучи участником совместных военных действий арабских племен и ромеев (Amm. Marc. XIV. 4.6), относится к сарацинам очень негативно и с досадой пишет о том, что римлянам лучше бы не иметь этих грабителей ни друзьями, ни врагами (Amm. Marc. XIV. 4.1). Автор приводит много примеров переменчивости настроений номадов, которое проявлялось в смене союзников, и часто подозревает их в предательстве (Amm. Marc. XIV. 3.1; XXIV. 2.4; XXV. 1.3; 6.8-9; Socr. H.E. VII. 18; Proc. Bell. I. 18.36). Но такое поведение сарацин вполне закономерно, поскольку они обитали в пограничных между двумя великими державами районах, натравливались ими друг на друга и 
использовались ими в интересах так же, как и кочевники в других областях, например, на Кавказе [Ермолова, 2007, с. 6].

Общепринятой в отечественной литературе является точка зрения, согласно которой в V-VI вв. главным союзником Византии на Востоке становится арабское племя Гассанидов. В настоящее время нет устоявшегося мнения среди ученых о статусе этого политического объединения в отношениях с Византией. Часть историков, вопреки устоявшемуся в литературе мнению, считает племена Гассанидов энспондами. Бесспорным остается тот факт, что предводитель союза племен Гассанидов был наделен титулом филарха и получал плату за оказание военной помощи империи [Серов, 2009, с. 200]. Эта помощь заключалась в охране восточных границ империи, а именно в борьбе с союзным Сасанидам арабском племени Лахмидов, а также в оказании союзной помощи империи во время военных кампаний (Iohann. Ephes., VI).

Данная модель политических отношений достигла своего расцвета во время правления Юстиниана Великого. Однако к концу VI в. союз Византии и Гассанидов фактически распался [Серов, 2009, с. 200].

Следующей важной вехой в арабо-византийских отношениях являются арабские завоевания VII в. До настоящего времени в научной литературе не сложилось однозначного мнения о причинах столь крупных успехов арабских войск на Востоке. Комплекс социально-экономических и идеологических факторов способствовал образованию мощной ударной силы, которая была способна к таким масштабным политическим действиям. Как известно, итогом арабских завоеваний для Византии стали большие территориальные потери на Востоке и в Африке, кроме этого были разрушены старые торгово-хозяйственные связи, империя утратила свой статус главной средиземноморской державы.

Говоря о месте Антиохии Великой в истории арабо-византийских отношений, следует заметить, что город не был пограничным и находился как бы на периферии контактов с арабскими племенами. Однако из источников мы можем узнать, что иногда грабительские походы арабов доходили вплоть до предместий Антиохии. Малала сообщает, что предводитель Лахмидов Аламундар, придя с персидским и сарацинским войском, ограбил Сирию Первую до границ Антиохии (Mal. XVIII. 33). Можно предположить, что Антиохия могла не опасаться арабских нападений в связи с тем, что это был большой, сильно укрепленный город, и у арабского войска, как правило, не было ни возможности, ни желания тратить на него свои силы. Общеизвестно, что основу арабского войска составляла легкая конница, а главным тактическим приемом были стремительные рейды по территории противника. В крупные сражения арабские военачальники предпочитали не ввязываться. Подтверждением нашего тезиса может служить вышеупомянутый текст Малалы: «...Услышав о случившемся, полководцы римлян устремились против него (Аламундара). Когда сарацины узнали это, они, забрав всю добычу, бежали за внешнюю границу...» (Mal. XVIII. 33). При этом известно, что арабские войска Лахмидов принимали участие в составе персидской армии, по крайней мере, в двух крупных походах на Антиохию.

Первый из них, поход 530 г., хотя и был неудачным для персидской армии, представляет для нас интерес, так как именно царю Лахмидов Мундару принадлежала идея направить поход не на Осроену и Месопотамию, а через Евфратесию на Сирию, которая, по его мнению, была плохо защищена, что стало ему известно от арабских лазутчиков. «Говорят, что там и город Антиохия, богатый, обширный, многолюдный, больше всех восточных ромейских городов, но его не оберегают, и он лишен войска» (Procop. Caesar. Bell. I. 17). Секретарь Велизария Прокопий Кесарийский подчеркивает, что самое опасное в этом походе берет на себя вождь Лахмидов: «ибо я поведу войско там, где, я полагаю, будет лучше всего», - он же позаботится о воде и припасах, что в условиях пути по пустыне было особенно важно» (Procop. Caesar. Bell. I. 17). Персы со своими арабами захватили ряд мелких городов и с помощью «деревянных машин» подкопали и свернули стены Габулы и вошли в город. Однако дальнейшее продвижение персов в направлении Антио- 
хии не было осуществлено (Mal. XVIII. 60). В последовавшем генеральном сражении этого похода племена Гассанидов и Лахмидов принимали очень активное участие.

Несмотря на то, что Антиохии удалось избежать нападения войск противника, на горожан этот поход произвел большое впечатление. Антиохийцы, услышав об успехах персов, «бежали на побережье Сирии» (Mal. XVIII. 60), и только успешные действия византийской армии сумели их успокоить.

Второй поход персов на Антиохию оказался гораздо более удачным. Весной 540 г. персидские войска под началом самого шаханшаха двинулись на Византию тем же путем, который был предложен Мундаром за 10 лет до того. На протяжении всего похода первого года об участии арабов в нем у Прокопия не упоминается. Однако следует предположить, что без их участия едва ли могла быть осуществлена кампания, их помощь требовалась и в пути, который был лучше всего известен им; они были быстроходным конным войском.

С первых побед шаханшаха было очевидно, что его целью не является завоевание, захват территории на длительное время. Это был поход, в котором важнейшей целью было ограбление и полон населения. Земли, которые были целью их похода, являлись исконными владениями империи, глубоко эллинизованными, составлявшими главную ее опору. Они не остались в длительном подчинении, как это доказали и походы на рубеже VI и VII вв. Византийские области недолго находились под владычеством персов.

Многие города смогли откупиться от персов и избежать захвата. Когда Антиохия не предоставила требуемого выкупа в 10 кентенариев, персидские войска двинулись на столицу Сирии. Антиохия была захвачена врагами и отдана им на разграбление. Богатейший город был опустошен; не только золото и серебро, драгоценная утварь, но великолепные мраморные изваяния были захвачены и увезены оттуда в Иран (Procop. Caesar. Bell. II. 5-9).

Походы Хосрова и, в частности, взятие Антиохии оставили глубокий след в памяти современников и упоминаются во множестве источников. Сирийская хроника Захарии Митиленского рассматривала взятие Антиохии как кару за отказ от монофизитства, анафематствование Севера и признание халкедонского вероисповедания [Пигулевская, 1964, c. 45]. У Михаила Сирийца сохранился рассказ о взятии Антиохии персидскими войсками. «Вновь выступил Хосров, и обложили персидские войска Антиохию, покорили ее, сожгли и полностью ограбили, забрали даже мраморные плиты, что были на стенах. Они [антиохийцы] были уведены в их землю и построили там город и назвали его Антиохия ... царь Юстиниан сильно оплакивал Антиохию» (Mich. Syr. 287).

Этот первый поход Хосрова в 540 г. известен и арабским источникам. Табари перечисляет захваченные Хосровом города в следующем порядке: «Дара, Эдесса, Маббог (Иераполь), Киннешрин (Халкис), Халеб (Беройа), Антиохия, самый значительный из городов Сирии, Апамея, Химс (Эмесса) и многие соседние области» были им захвачены силой, а «деньги и имущество из городов взято в качестве добычи» [Пигулевская, 1964, с. 46].

Помимо непосредственных контактов с арабскими и персидскими войсками, антиохийцам приходилось иметь дело с последствиями их грабительских походов. Иоанн Малала в своей «Хронографии» сообщает об одном эпизоде. Пленники сарацина Аламундара обратились с жалобой к патриарху Ефремию на жестокое обращение. Некоторые из них были казнены. Пленникам удалось убедить Аламундара отправить в римское государство просьбу, чтобы прислали денег на их выкуп. О посланной жалобе стало известно в Антиохии, и всякий, кто мог, со слезами относил что-то в так называемые казнохранилища, [находившиеся] в каждой церкви. Первыми добровольно внесли свою долю опечаленный патриарх, клирики и архонты. Когда же просьба, посланная пленниками, была прочитана, весь народ попросил устроить собрание. Во время собрания был разостлан ковер, и каждый бросал на него, что мог. Когда все было собрано и отослано, пленники были освобождены (Mal. XVIII. 59). 
Таким образом, в доисламский период контакты Антиохии и арабских племен имели несколько форм. Это были грабительские походы арабов, которые иногда доходили до предместий Антиохии, однако, как мы уже могли убедиться, прямой угрозы городу они не несли. Также арабские войска принимали участие в крупных походах персидской армии, где играли важную роль и как боевая единица, и как опытные проводники. Кульминацией истории отношений города с арабами стали его захват и разграбление во время византийско-персидских войн при Юстиниане: падение города случилось в 540 г., однако затем он был вновь отстроен.

Кроме этого, антиохийцам приходилось «устранять» последствия арабских походов, выкупая пленников, отправляя ремесленников на восстановление разрушенных городов. На наш взгляд, заслуживает внимания точка зрения, согласно которой нестабильная обстановка в городе, связанная с религиозными, политическими и этническими волнениями, не позволяла имперским войскам ослабить свое внимание к городу и перебросить часть войск к границам империи, тем самым уменьшив роль арабских племен в охране границ империи.

VII век известен в мировой истории как время появления ислама, последовавших за этим арабских завоевательных походов и создания Арабского Халифата. Для Антиохии VII век становится периодом завершения истории Антиохии как ранневизантийскогопозднеантичного города.

Укажем причины, которые способствовали столь стремительному арабскому завоеванию восточных провинций Византии.

Ряд исследователей полагает, что прогресс общества связан с изменениями, улучшавшими орудия производства. Для кочевника одним из таковых является сбруя животного, осуществляющего его передвижение. Среди таких новшеств, которые начали использоваться арабами к VII веку, можно назвать перемещение всадника ближе к голове верблюда, на его горб, что облегчало его вождение. Изменение в позиции всадника стало возможно лишь с изменением седла, которое приобретает новую форму. Это седло с подушками характерно для положения всадника на горбе, которое засвидетельствовано для $\mathrm{IX}$ в. и, вероятно, использовалось уже столетием или двумя ранее. Еще более высокая боеспособность арабов была достигнута в связи с усовершенствованием оружия. Закалка клинков, придававшая им особую гибкость и остроту, получила позднее название «дамасской». Следует также указать на значение панциря, кольчуги, предохранявшей воина от ударов оружия. Всадник в панцире получает очень большие возможности, он ведет бой особенно успешно, так как он на коне и его оберегает панцирь [Пигулевская, 1964, с. 109].

Несмотря на то, что среди исследователей до сих пор ведутся споры относительно правильности применения термина «священной войны» или «джихада» к арабским завоеваниям VII века, ведущая роль ислама в жизни нового арабского государства, на наш взгляд, является неоспоримой [Алиев, 2006, с. 220-221; Люттвак, 2016, с. 284-285].

Не стоит забывать и о геополитическом контексте, сложившемся на восточных границах Византии. В результате перманентной вооруженной борьбы Персия и Константинополь обескровили друг друга и уже не могли достойно противостоять новому сопернику в лице молодого Арабского Халифата.

Безусловно, побед на поле боя для завоевания и длительного удержания таких обширных территорий недостаточно. Из истории римско-персидских войн мы видим, что территории, исторически принадлежащие противнику, не были оккупированы на долгий срок. К началу VII века в Антиохии, как и во всей Сирии, накопилось достаточное количество претензий к императорской власти. В городе была сложная экономическая и этнорелигиозная обстановка, процветали сепаратистские настроения.

Ко времени арабских вторжений в имперской казне отсутствовали бюджетные излишки, которые можно было бы скопить. За тридцать лет предшествующей войны с Ираном расходы значительно увеличились, а вот поступления в казну сократились, вслед- 
ствие чего казна оказалась почти пустой. Феофан в своем труде указывает, что к 622 году Ираклий начинает переплавлять церковную утварь храма св. Софии в деньги. Налоги приходиться собирать с Сирии и Египта сразу после того, как они были отвоеваны у персов. В период сасанидской оккупации завоеванные земли также подвергались налоговому обложению. Во время войн земли подвергались грабежам. Таким образом, нестабильное экономическое положение местного населения и постоянный налоговый гнет не вызывали у антиохийцев и сирийцев желания вести борьбу с арабскими захватчиками и возвращаться в состав Византийской империи.

Другое отношение было к податному населению и иным конфессиям со стороны властей Арабского Халифата. Известно, что немусульманское население на завоеванных арабами территориях подвергалось религиозной и экономической дискриминации. Язычников, отказавшихся принять ислам, полагалось убивать, но в Антиохии и округе таковых к началу VII века было мало, и они умели скрываться. Христианам и иудеям - т. н. «людям книги» - было позволено жить спокойно в статусе безоружных «покровительствуемых» граждан второго сорта, они должны были платить джизью - подушную подать - и освобождались от воинской обязанности.

Особенностью арабской дискриминации было то, что новые власти одинаково относились ко всем категориям христиан, никого отдельно не выделяя. Конфессиональная ненависть на Востоке была столь сильна, что зачастую халкидониты выступали для монофизитов большими врагами, нежели арабы.

Незадолго до своей смерти Ираклий пытался унять религиозные споры в империи, однако, как мы помним, эта попытка не увенчалась успехом. «Анонимная сирийская хроника 1234 г.», написанная монофизитом, рассказывает о том, как Теодорих, брат императора Ираклия, проходил со своим войском через Сирию, чтобы сразиться с арабамимусульманами. Затем он должен был подвергнуть гонениям севериан при поддержке значительной части населения. С явным удовольствием автор описывает, как войско Теодориха было разбито [Люттвак, 2016, с. 297]. У Иоанна Никиусского можно встретить описание настроений, царивших среди монофизитов в Александрии, и это подробное описание, на наш взгляд, вполне можно экстраполировать и на Антиохию. По мнению горожан, изгнание ромеев и победы мусульман случились из-за порочности императора Ираклия и его гонений на православных, проводившихся руками патриарха Кира (John Nik. CXX. 72; CXXI. 1).

Иудейское население Востока империи и, по всей видимости, Антиохии также приветствовало арабское завоевание. При арабской дискриминации царило полное равенство между покоренными группами населения, и иудеям были представлены те же самые ограниченные, но постоянные права, что и другим зимми [Люттвак, 2016, с. 299].

В Византии же все было гораздо хуже. Еще в V веке в кодексе Феодосия всем, кто живет в «иудейском предрассудке», запрещалось занимать посты на государственной службе. Однако не стоит забывать, что образованным иудеям, обучившимся свободным искусствам, не запрещалось занимать должности куриалов, которые им полагались по прерогативе рождения (CTh. XVI. 18. 24). В частности, крупная иудейская община была в Антиохии, участвуя в местном самоуправлении. О близости антиохийской муниципальной аристократии с верхушкой иудейской общины говорит тот факт, что некоторые представители последней учились вместе с антиохийскими куриалами в муниципальной школе и получали высшее греческое образование. Племянник патриарха иудеев Гамалиила был одним из любимых учеников Либания. Не случайно и реставрация Юлиана сопровождалась поддержкой иудейских культов в Антиохии.

В период правления Феодосия еврейская община процветала. Существовали две синагоги, одна в Антиохии, другая в Дафне. Возможно существование и других синагог, о которых не осталось упоминаний в источниках [Downey, 1961, p. 447-449]. Однако жизнь иудеев в Антиохии нельзя назвать исключительно мирной. Во время правления императо- 
ра Зенона известны случаи, когда цирковая партия Зеленых совершала нападения на иудейскую общину города. Малала сообщает, что действия Зеленых против иудеев были доведены до сведения императора Зенона. Он рассердился на Зеленых в Антиохии, вопрошая: «Почему они жгли только трупы иудеев? Они должны были сжечь также и живых евреев». Это заставило замять дело (Mal. XV. 15).

До VI века иудеи еще пользовались юридической защитой от насилия, закрепленной в Кодексах Феодосия (CTh. XVI. 8.21) и Юстиниана (Codex Justinianus I. 9.14), однако иудеям запрещалось строительство новых синагог, а за обращение в иудаизм христианина полагалась смерть, при том что любой из крестившихся наследников иудеев получал все наследство целиком (Cod. Just. I. 5.13).

В VII веке ситуация с иными конфессиями не улучшилась. К началу века всех нехристиан в пределах империи либо заставили креститься под страхом смерти, либо просто перебили. Только иудеям было позволено жить как нехристианам, хотя эта жизнь не была ни хорошей, ни спокойной. В текстах можно встретить описания вооруженных столкновений между иудеями и христианами в Антиохии и в других частях империи в период правления императора Фоки. Известно также, что Фока обложил штрафами евреев в Антиохии, Лаодикее и других городах (Agapius, 8. 449). Тысячи беженцев перемещались на территорию, занятую персами.

Мы видим, что причин хранить верность империи ни у монофизитского, ни у иудейского населения Антиохии практически не было.

В свою очередь, перед походом на Сирию в 634 г. Абу Бакр следующим образом инструктировал ополчение мусульман: «Никого не обманывайте и не крадите; не поступайте вероломно; не увечьте и не умерщвляйте детей, стариков и жен; не сдирайте коры с пальм и не жгите; не рубите плодовые деревья; не уничтожайте посевы; не умерщвляйте овец, быков, верблюдов сверх того, что понадобится для поддержания жизни. Когда встретитесь с отшельниками, - напутствовал первый халиф, - не трогайте их». «Если провинция или народ признают тебя, - наставлял одного из своих наместников Абу Бакр, - то заключи с ними соглашение и держи свое обещание. Пусть они руководствуются своими законами и установленными обычаями, собирай с них дань так, как договоришься с ними. Оставь им их религию и землю».

Возникает вопрос, какое соглашение подразумевает здесь Абу Бакр. Во времена завоевательных походов до начала решающих действий мусульманам предписывалось инициировать подписание с противником мирного договора о защите (акд аз-зимма). Если соглашения достичь не удавалось, то боевые действия возобновлялись и продолжались до победы одной из сторон. В случае подписания этого документа иноверное население покоренных арабами городов или областей включалось в категорию ахл аз-зимма (зимми, зиммиев) - людей, платящих налоги (поголовный, джизйа, и поземельный, харадж) и находящихся под защитой и покровительством мусульманского государства. Им разрешалось (с некоторыми ограничениями) исповедовать веру предков, а также гарантировалась свобода личности и имущества [Алиев, 2006, с. 224].

Арабский захват Антиохии произошел очень быстро. Когда войска халифата начали свое наступление на Сирию и Палестину в 634 г., Ираклий сделал Антиохию своей штаб-квартирой. После решительной победы исламских войск в битве при Ярмуке в августе 636 г. стало ясно, что спасти Сирию невозможно, император покинул Антиохию и удалился в Константинополь [al-Baladhuri, 1916, p. 175, 176, 189, 210].

В 637-638 гг. арабы занимают города северо-западной Сирии [Downey, 1961, p. 551]. Завоевание далось довольно легко, и не последнюю роль в этом сыграли монофизиты, освобождавшиеся таким образом от контроля имперского правительства. Завоеватели предлагали жителям выбор: уходить во владения Византии или оставаться и платить дань. Вскоре войска заняли Халкиду - один из военных центров Сирии. Бежавшие из города войска перешли в Антиохию, где планировали дать врагу отпор. Однако, когда арабы 
оказываются под крепостными стенами, город, после недолгого сопротивления, сдался на условиях, предложенных завоевателями. Известно, что большая часть жителей города не покинула, приняв власть Халифата [Hitty, 1956, p. 152, 153].

Следует отметить, что все крупные города этого региона (Киннесрин, Халеб (Алеппо), Антиохия, Тир, Сидон, Газа, Рамла и др.) были сданы арабам на основании мирных договоров, аналогичных тому, что был заключен при падении Дамаска. Текст соглашения Халида с жителями Дамаска привел в «Книге завоеваний стран» («Китабфутух ал-булдан») известный мусульманский историограф Абу Бакр Ахмад ал-Балазури (ок. 820-892/93 гг.): «Во имя Аллаха милостивого, милосердного. Это - то, что Халид ибн альВалид дает жителям Дамаска, если он вступит в город. Он им дает гарантию неприкосновенности их жизни, их имущества, их церквей и городских стен. Ни одно из жилищ не будет разрушено или заселено [мусульманами]. На этом им - завет Аллаха, покровительство его посланника... халифов и верующих. Пока жители Дамаска будут платить подушную подать, с ними, кроме добра, ничего не будет сделано» [Алиев, 2006, с. 225-226]. Равным образом эти условия должны были быть прописаны в договоре с антиохийцами.

Арабские источники дают понять, что завоеватели считали захват Антиохии задачей первостепенной важности. После взятия города в нем был размещен сильный гарнизон [Theophanis, 1883-1885, p. 337].

Интересно, что знаменитые своим непокорным нравом антиохийцы оказались довольно своенравными подданными и в период арабского владычества. Сохранился отчет, согласно которому Антиохия, как и некоторые другие из недавно оккупированных городов, очень скоро восстала против новых хозяев и была усмирена с помощью силы, но детали этого восстания до сих пор не известны.

Все эти события являются концом истории Антиохии как города, принадлежавшего к греко-римскому миру [Elderkin, Stillwell, 1939-1952].

\section{Заключение}

Таким образом, на протяжении IV-VII вв. складывались устойчивые связи и отношения византийцев с арабским миром. Антиохия была важным стратегическим пунктом, в котором происходило пересечение контактов арабов и византийцев. Арабы в доисламский период вели кочевой образ жизни, расселяясь на обширных просторах в пограничье между византийскими и персидскими владениями. Антиохия же была столицей Востока, находясь вблизи от этого региона, и не могла не привлекать внимание арабов, однако не настолько близко, чтобы сложились тесные контакты между арабскими племенами и городом. В силу своей удаленности от основных зон контактов Антиохия была на периферии культурных связей, однако в политическом и экономическом отношении оставалась привлекательной для арабских набегов. Арабские племена доходили до предместий Антиохии и самого города в ходе набегов в русле визанийско-персидских войн, выступая как союзники персов. В ходе войн Юстиниана с персами в 1-й пол. VI в. (530-540-е гг.) Антиохия стала одним из объектов персидских завоеваний, будучи разграблена в 540 г. Однако она осталась под византийским контролем, а персидские войска и их арабские союзники отступили на свои территории. Иная ситуация сложилась в 30-е годы VII в., когда состоялось полномасштабное завоевание Антиохии силами Арабского Халифата. Легкость, с которой это было осуществлено, была связана не только с усилившейся военнополитической мощью арабов, но также с внутренними противоречиями между самой Антиохией и центральной властью Византийской империи, а именно репрессивной конфессиональной политикой властей по отношению к населению города, большую часть которого составляли христиане монофизитского толка и иудеи, особенно на протяжении 2-й пол. V - начала VII вв. В Арабском Халифате положение иных конфессий было существенно легче, а сами условия сдачи и перехода под власть арабов были умеренные и приемлемые. Этим была обусловлена окончательная потеря Антиохии для греко-римского 
мира и ее интеграция в культуру исламского Ближнего Востока в 1-й пол. VII в. [Downey, 1963], несмотря на временное возвращение в состав Византии позднее.

\section{Список литературы}

1. Алиев А.А. 2006. «Священная война» в политической культуре ислама VII-VIII вв. (исторический ракурс проблемы). Политическая наука. 3: 220-239.

2. Аммиан Марцеллин. 1906-1908. История. Пер. с лат. Ю.А. Кулаковский, А.И. Сонни. Вып. 1-3. Киев, 446.

3. Грушевой А.Г. 2007. Принципы взаимоотношений Рима и ранней Византии с аравийскими кочевниками. Мнемон. Исследования и публикации по истории античного мира. Вып. 6. СПб.: 337-366.

4. Иоанн Малала. 2014. Хронография. Книги XIII-XVIII. Пер. с греч. Мир поздней античности. Вып. 2. Белгород, БелГУ, 200.

5. Люттвак Э.Н. 2016. Стратегия Византийской империи. Пер. с англ. А.Н. Коваля. М., Русский фонд содействия образованию и науке, 664.

6. Мехамадиев Е.А. 2018. Войсковые подразделения Agrarienses и ближневосточная граница поздней Римской империи в 333-337 гг.: сведения эпиграфики. Вестник Нижегородского университета им. Н.И. Лобачевского. 2: 37-47.

7. Пигулевская Н.В. 1964. Арабы у границ Византии и Ирана в IV-VI вв. М., Л., Наука, 336.

8. Прокопий Кесарийский. 1993. Война с персами. Война с вандалами. Тайная история. Пер. с греч., ст. и комм. А.А. Чекаловой. М., Наука, 512.

9. Серов В.В. 2009. Ранневизантийская дипломатия в 60-70-х годах. Известия Алтайского государственного университета. 4-1: 195-201.

10. Сирийские источники XII-XIII вв. об Азербайджане. 1960. Баку, Изд-во АН АзССР, 181.

11. Сократ Схоластик. 1996. Церковная история. М., Российская политическая энциклопедия, 368.

12. Феодорит, еп. Кирский. 1993. Церковная история. Пер. с греч. М., Российская политическая энциклопедия; Колокол, 239.

13. Agapius of Menbidj. 1910. Universal History. Patrologia Orientalis. Paris, 870.

14. al-Baladhuri, Ahmad ibn Yahya. 1916. The origins of the Islamic state: being a translation from the Arabic. New York, Charles, 433.

15. Charles R.H. 2007. The Chronicle of John, Bishop of Nikiu: Translated from Zotenberg's Ethiopic Text. Oxford, UP, 251.

16. Downey G. 1961. A history of Antioch in Syria from Seleucus to the Arab Conquest. Princeton, New Jersey, Princeton University Press, 790.

17. Downey G. 1963. Ancient Antioch. Princeton, UP, 342.

18. Elderkin G.W., Stillwell R. 1939-1952. Antioch on the Orontes. Princeton, UP. Vol. 1-4.

19. Shahid I. 1995. Byzantium and the Arabs in the Sixth Century. Vol. 1, p. 1. Washington, DORLC, 712.

20. Theophanis. 1883-1885. Chronographia. Rec. C. de Boor. Vol. II. Lipsiae, Teubner Verlag, 856.

\section{Referenses}

1. Aliev A.A. 2006. «Svyashhennaya vojna» v politicheskoj kul ture islama VII-VIII vv. (istoricheskij rakurs problemy`) [«Holy War» in the Political Culture of Islam in the 7th -8 th centuries (historical perspective of the problem)]. Politicheskaya nauka [Political Science]. 3: 220-239.

2. Ammian Marcellin. 1906-1908. Istoriya [History]. Per. s lat. Y.A. Kulakovski, A.I. Sonni.Vyp. 1-3. Kiev, 446.

3. Grushevoj A.G. 2007. Principy` vzaimootnoshenij Rima i rannej Vizantii s aravijskimi kochevnikami [The principles of the relationship between Rome and early Byzantium with the Arabian nomads.]. Mnemon. Issledovaniya i publikacii po istorii antichnogo mira [Mnemon. Research and publications on the history of the ancient world]. Vy`p. 6. SPb.: 337-366.

4. Ioann Malala. 2014. Hronografija. Knigi XIII-XVIII [Chronography. Books XIII-XVIII]. Mir pozdnej antichnosti [World of Late Antiquity]. Vyp. 2. Belgorod, BelGU, 200. 
5. Lyuttvak E.N. 2016. Strategiya Vizantijskoj imperii [Byzantine Empire strategy]. Per. s angl. A.N. Kovalya. M., Russkij fond sodejstviya obrazovaniyu i nauke. 664.

6. Mexamadiev E.A. 2018. Vojskovye podrazdeleniya Agrarienses i blizhnevostochnaya granicza pozdnej Rimskoj imperii v 333-337 gg.: svedeniya epigrafiki [Troops of the Agrarienses and the Near Eastern Border of the Late Roman Empire in 333-337: Epigraphic Information]. Vestnik Nizhegorodsko gouniversiteta im. N.I. Lobachevskogo [Bulletin of the Nizhny Novgorod University. N.I. Lobachevsky]. 2: 37-47.

7. Pigulevskaya N.V. 1964. Araby`u granicz Vizantii i Irana v IV-VI vv. [Arabs at the borders of Byzantium and Iran in the IV-VI centuries]. M., L., Nauka. 336.

8. Prokopij Kesarijskij.1939. Vojna s persami. Vojna s vandalami. Tajnaya istoriya [The war with the Persians. War with the Vandals. Secret story]. Per., st. i komm. A.A. Chekalovoj. M., Nauka, 512.

9. Serov V.V. 2009. Rannevizantijskaya diplomatiya v 60-70-x godax [Early Byzantine diplomacy in the 60s and 70s]. Izvestiya Altajskogo gosudarstvennogo universiteta [Bulletin of Altai State University]. 4-1: 195-201.

10. Sirijskie istochniki XII-XIII vv. ob Azerbajdzhane [Syrian sources XII-XIII centuries about Azerbaijan]. 1960. Baku, Izd-vo AN AzSSR, 181.

11. Sokrat Sholastik. 1996. Cerkovnaja istorija [Church history]. M., Rossijskaja politicheskaja jenciklopedija, 368 .

12. Feodorit, ep. Kirskij. 1993. Cerkovnayaistoriya [Church history]. Per. s grech. M., Rossijskaya politicheskaya enciklopediya; Kolokol, 239.

13. Agapius of Menbidj. 1910. Universal History. Patrologia Orientalis. Paris, 870.

14. al-Baladhuri, Ahmad ibn Yahya. 1916. The origins of the Islamic state: being a translation from the Arabic. New York, Charles, 433.

15. Charles R.H. 2007. The Chronicle of John, Bishop of Nikiu: Translated from Zotenberg's Ethiopic Text. Oxford, UP, 251.

16. Downey G. 1961. A history of Antioch in Syria from Seleucus to the Arab Conquest. Princeton, New Jersey, Princeton University Press, 790.

17. Downey G. 1963. Ancient Antioch. Princeton, UP, 342.

18. Elderkin G.W., Stillwell R. 1939-1952. Antioch on the Orontes. Princeton, UP. Vol. 1-4.

19. Shahid I. 1995. Byzantium and the Arabs in the Sixth Century. Vol. 1, p. 1. Washington, DORLC, 712.

20. Theophanis. 1883-1885. Chronographia. Rec. C. de Boor. Vol. II. Lipsiae, Teubner Verlag, 856.

\section{ИНФОРМАЦИЯ ОБ АВТОРАХ}

\begin{abstract}
Иваницкая Яна Юрьевна, кандидат исторических наук, учитель МОУ «Стрелецкая СОШ» Белгородского района Белгородской области
\end{abstract}

Немыкина Елена Валерьевна, учитель МОУ «Стрелецкая СОШ» Белгородского района Белгородской области

Бузанаков Юрий Владимирович, аспирант кафедры всеобщей истории Белгородского государственного национального исследовательского университета, г. Белгород, Россия

\section{INFORMATION ABOUT THE AUTHORS}

Yana Yu. Ivanitskaya, candidate of Historical Sciences, teacher of the Municipal educational institution «Streletskaya Secondary School» of the Belgorod District of the Belgorod Region, Russia

Elena V. Nemykina, teacher of the Municipal educational institution «Streletskaya Secondary School» of the Belgorod District of the Belgorod Region, Russia

Yuriy V. Buzanakov, post-graduate student of the Department of General History, Belgorod State National Research University, Belgorod, Russia 